\title{
El collar de la paloma. Tratado sobre el amor y los amantes
}

\author{
Paulina López Pita*
}

\begin{abstract}
RESUMEN
Se recoge en este trabajo la opinión que algunos estudiosos han dado sobre una de las mejores obras de la literatura árabe, calificada por don Emilio García

Gómez de auténtica joya literaria. Su autor, el ilustre polígrafo cordobés, Ibn Hazm (994-1064), comenzó a escribirla

en el año 1022 en unas duras condiciones, como él mismo reconoce, cuando se hallaba cautivo en Játiva. Por entonces, el califato cordobés mostraba ya sus primeros sintomas de debilidad.

Esta obra esta escrita en árabe purísimo y en rica prosa en la que se intercalan versos con un profundo sentimiento. En ella su autor nos narra aspectos del amor basados en su propia experiencia, y en lo que le contaron gentes de fiar, transmitiendo, en suma, como amaron las gentes de

al-Andalus durante el gobierno de la dinastía omeya; por este motivo, algunos consideran, en parte, este libro como la autobiografía de su autor y de
\end{abstract}

\section{ABSTRACT}

This report contains some opinion from several experts about one of the masterpieces of the arab literature, considered as an authentic jewel by Emilio García Gómez. Its author, the famous cordovan polygraph $\mathrm{lbn}$ Hazm (994-1064), started to write it in 1022, under hard living conditions, when he was in prison in Játiva.

By then, the cordovan caliphate showed its first symptoms of weakness.

This work is written in a very pure arab and in rich prose, in which some verses are intercalated with a deepe feel. There, its author writes about some love aspects based on his own experience and on the testimony of reliable people, transmitting the way in which people from al - Andalus loved during the Omeya dinasty; for this reason, some people partially consider this book as the author's, and the people sorrownding him, autobiography.

* UNED. 
las gentes que le rodearon.

Ibn Hazm compuso esta obra por encargo de un amigo y a través de ella

le ofrece, por la amistad que les une, "ayuda" para alcanzar la verdad. En los sucesivos capítulos de que consta «El collar", el autor nos habla de los fundamentos del amor, entre los que destaca, la esencia del amor, las formas de enamoramiento,etc... de los accidentes del amor y de sus cualidades loables y vituperables; de las malaventuras que sobrevienen al amor, de la fealdad del pecado y de la castidad. No obstante, a pesar del plan previo establecido por el autor, estos temas se mezclan unos con otros, $y$ de ello se excusa Ibn Hazm.

"El collar de la paloma" ha tenido una gran divulgación, siendo traducido a las principales lenguas, $y$ en él han querido encontrar, estudiosos de la literatura medieval ciertas similitudes.
Ibn Hazm composed this work for a friend, in which he offers him, for friendship reasons, some help to achieve the truth. Along the next chapters of «El collar», the author talks about the foundations of love, among which he emphasizes the essence of love, the ways to fall in love, etc., the accidents of love, the laudable qualities and defects; the misfortunes after the love, the uglyness of sin and the chastity. Nevertheless, although there is a previous plan foreseen by the author, these aspects are mixed between them, and Ibn Hazm apologizes for that. "El collar de la Paloma" has become very popular, having been traslated to the main languajes, and in which some medieval literature specialists have wanted to find some similarities.

\section{ALGUNOS DATOS SOBRE LA VIDA Y PERSONALIDAD DE SU AUTOR:IBN HAZM}

Abu Muhammad 'Ali lbn Hazm nació el 7 de noviembre del año 994 (miércoles 30 de ramadán del año 384) en Córdoba, ciudad que fue durante siglos el centro de irradiación de la cultura de toda Europa, en ella convergieron y se enriquecieron mutuamente, a través del Islam, las culturas de Oriente y Occidente. No obstante, cuando esto ocurre, la capital de la España Musulmana se encontraba en uno de los momentos más trágicos de su historia, pues el califato cordobés había dado muestras de su debilidad y los primeros síntomas de su descomposición se hacían evidentes.

Ibn Hazm pertenecía a una familia muladí, recién convertida al Islam, aspecto éste que tratará de ocultar. Su abuelo, SA'ID, abandonó Huelva donde vivía dedicándose a la explotación de fincas rústicas, y se instaló, en el siglo $x$ en la esplendorosa ciudad de Córdoba en busca de fortuna. El padre de Ibn Hazm, AHMAD, hombre culto, supo moverse dentro de los medios políticos llegando a ser nombrado visir de Almanzor, motivo por el cual abandonó la casa en la que vivía con su familia en el barrio de 
Balat Mugit, al poniente de la ciudad, de la que tan buenos recuerdos tenía Ibn Hazm como señala en "El collar de la paloma" ", para instalarse cerca de Madinat al-Zahira, la nueva ciudad próxima a Córdoba, donde Almanzor había ordenado trasladar la corte.

Los primeros años de la vida de este ilustre poeta transcurrieron en el ambiente de esta familia de la nueva aristocracia, viviendo con lujo y bienestar, en el más alto nivel de la vida cordobesa. Ibn Hazm como él mismo menciona en «El collar de la paloma» se educó dentro del harén donde se le revelaron temprano los misterios de la vida sexual y los tejemanejes del serrallo, de ahí los versos que compuso:

"Yo he intimidado mucho con mujeres y conozco tantos de sus secretos, que apenas habrá nadie que los sepa mejor, porque me crié en su regazo y creci en su compañia, sin conocer a nadie más que a ellas.... me enseñaron el Alcorán, me recitaron no pocos versos y me adiestraron a tener buena letra..."

"No olvidé nada de lo que en ellas vi. Acaso por esto nació en mi una intensa desconfianza contra las mujeres, y la mala opinión que las tengo, que se ha hecho congénita en mi alma»?.

Ibn Hazm recibió la educación de manos de los maestros más célebres de Córdoba: Ibn Yasur; Ibn Yahhaf $(+1010)$ de quien dijo Ibn Hazm: «fue el más excelente qadí que yo he conocido, en religión, inteligencia y continencia, con extensos conocimientos cientificos»; el historiador Ibn Faradi $(+1013)$ y otros muchos más, según recoge su biógrafo Al-Humaydi $(+1095)$ quien dedica al poeta cordobés cálidos elogios ${ }^{3}$.

Antes que Ibn Hazm publicase ninguna obra importante, salvo poemas cortos o breves composiciones, y sin tener tampoco un empleo estable, cuando contaba 18 años, su padre, de quien había recibido numerosas recomendaciones sobre su actitud, murió en 1012. Entre los recuerdos juveniles de Ibn Hazm sobre las recomendaciones que le hizo su padre hay uno que se menciona a menudo y que queda reflejado en este verso:

\footnotetext{
1 Cuando se hallaba en el exilio, Ibn Hazm pide a un amigo que le refiriese lo que sucedía en Córdoba, y áquel le cuenta el estado ruinoso en el que se encontraban sus casas, "sus huellas se habian borrado, sus vestigios desaparecido, y a penas se saben donde están». Y menciona, a propósito de lo relatado, «todo esto me hace recordar los dias que pasé en aquellas casas, los placeres que gocé en ellas y los meses de mi mocedad que alli transcurrieron...» Cfr. GARCíA GómeZ, E.: El collar de la paloma, Madrid. Alianza Edit. $3 .^{a}$ ed. 1971, págs. 227-228.

2 Cfr. García Gomez, E.: op. cit. p. 167.

3 Cfr. Teres, E.: «Enseñanzas de Ibn Hazm en la «Yadwat al-Muqtabis» de Al-Humaydi». Al-Andalus, XXIX, 1964, págs. 147-178.
} 
«Si quieres ser rico, procura contentarte con una posición social inferior a la que posees" ".

Al año de morir su padre, en mayo de 1013, Córdoba es destruida y pasa a manos de los beréberes. Ibn Hazm fiel a la dinastía de los Omeyas, se vio obligado a salir de Córdoba y se instaló en Almería con su amigo Ibn Ishaq. La tranquilidad que allí encontraron al principio, no duró mucho, pues estos dos jóvenes legitimistas omeyas fueron acusados de conspiración y fueron desterrados. Ibn Hazm se refugia en Aznalcázar, lugar situado entre Málaga y Murcia, durante un corto espacio de tiempo, pues enterado de que en Levante un nuevo pretendiente omeya se estaba preparando para enfrentarse a la dinastía de los Hammudies, se dirigió junto con su amigo a aquel lugar para prestarle su ayuda. No tuvieron éxito e Ibn Hazm, después de sufrir cautiverio, se refugió en Játiva donde comenzó a escribir su famosa obra «El collar de la paloma» (1022).

A pesar de todo, en 1024, cuando el califato Hammudi, que habia gobernado en Córdoba, toca a su fin, Ibn Hazm volvió a la vida política siendo nombrado visir del nuevo califa omeya, Mustazhir; cargo que desempeñó mes y medio, pues Mustazhir fue ejecutado e Ibn Hazm conducido, de nuevo, a la cárcel.

Cuando Ibn Hazm abandona el cautiverio se da cuenta de que todo está perdido (Córdoba tardó 7 años más) y se retira definitivamente de la política activa, para dedicarse al estudio de la ciencia jurídico-teológica por la que siempre se había interesado. A partir de entonces los datos que tenemos de él serán en relación con sus obras, pues muy poco se nos ha transmitido de su vida privada.

Su pensamiento, como veremos posteriormente, se aferró a la escuela zahirí. Mantuvo una voluntad sistemática de sujetarse a la letra del Corán y de la Sunna, (zahiriyya). Preocupado por proclamar lo que está permitido y lo que no lo está, no tiene mucha cuenta ni de lo real ni de lo posible, únicamente considera lo que debe ser ${ }^{5}$.

Su pertenencia a esta corriente le granjeó numerosos enemigos entre los alfaquíes de la escuela maliki imperante en Córdoba, quienes

4 Este pensamiento ya fue reflejado en la filosofia antigua: «No hay pobre sino quien se estima serlo»; y fue repetido posteriormente en el estribillo de una canción castellana del s. XVII: «No es pobre quien poco tiene, más el que mucho desea». Cfr. TEREs, E.: op. cit. págs. 152-3.

5 Fr. Garaudy, R.: El Islam en Occidente. Córdoba, capital del pensamiento unitario. Madrid, Breogan, 1987. 
instigaron ante $\mathrm{lbn}$ 'Abbad, para que sus obras personales fueran quemadas. Es entonces cuando Ibn Hazm compuso aquellos versos tan famosos:

"Si quemáis el papel, no quemáis el pensamiento a él confiado, y menos aún el que está en mi cerebro" ${ }^{\circ}$.

No obstante, son de enorme interés los rasgos de su personalidad que el propio Ibn Hazm nos ofrece en distintos capítulos de su obra, cuando manifiesta ciertas reflexiones sobre su modo de pensar, de actuar, de sus amores, de sus cualidades o creencias.

Ibn Hazm valoraba la amistad con sus amigos y son muchas las referencias que a ella hace en "El collar de la paloma". Así, por ejemplo, manifiesta, al referirse al afecto que había perdido con uno de sus amigos, que «era de naturaleza ponderado, sufrido y manso en cuanto podía.. y, por ello, encontró la manera de restablecer su amistad ${ }^{7}$ ».

Esa amistad tratará de mantenerla incluso con el amigo que acabó portándose mal con él, después de haberse tenido un sincero afecto, al divulgar todo lo que por el grado de confianza que entre ellos había conocía de su persona, pero lbn Hazm, en vez de corresponderle de igual manera, contando todo lo que sabía de él, le escribió una poesía en que lo tranquilizaba y le hacía saber que no pensaba medirle con el mismo rasero ${ }^{8}$.

En su carácter, como el mismo pone de manifiesto, existían dos rasgos congénitos, por los cuales no le había sido agradable jamás la vida: uno de ellos es la lealtad, nacida de una propensión social que hace que su alma no pueda apartarse de quien ha conocido ni desear la desaparición de quien ha tratado; el otro es un amor propio que rechaza toda ofensa, se afecta por la más pequeña mudanza que advierte en los amigos y prefiere la muerte a sufrirla. La conjunción de estas dos cualidades, cada una de las cuales le atrae a su bando, le llevaban a padecer un gran tormento ${ }^{9}$.

Más adelante, se jacta, de nuevo, de ser leal, pues nada había para él más insoportable que la traición, y nunca se perdonaría a sí mismo pensar en hacer daño a aquél con quien le ha unido la menor obligación por muy

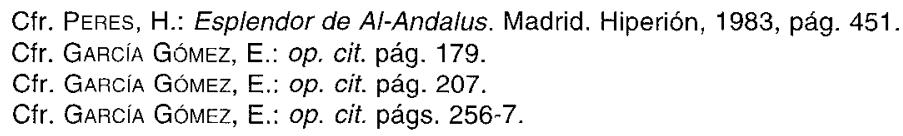


grande que fuese su delito y por muchas faltas que hubiese cometido en contra suya ${ }^{10}$.

De la vida amorosa de Ibn Hazm sabemos lo que él mismo confiesa al escribir «El collar de la paloma». Recuerda como, en ocasiones, se sintió atraído por jóvenes esclavas que había en su casa, una de las cuales, que no le correspondía, tañía el laúd de forma maravillosa; pero fue de una esclava, llamada Nu'm, que tuvo cuando tenía 20 años, de quien se enamoró perdidamente, sintiendo una pasión como nadie tuvo. Fue para ella su primer amor, pero la muerte prematura se la arrebató. Confiesa que siete meses después de perderla estuvo sin desnudarse de sus ropas, y que jamás, después de perderla, encontró placer en la vida. Su amor por esta muchacha borró todos los que le precedieron e hizo imposibles los siguientes ${ }^{11}$.

Poco más refiere lbn Hazm de su etapa posterior, sabemos que tenía mujer e hijos, pues a ellos alude al final de su obra, al referir como se esfuerza por sacarlos adelante ${ }^{12}$.

En suma, para concluir estos datos biográficos, citaré unos arrogantes versos en los que Ibn Hazm, nos desvela las aspiraciones inquietas de su alma, que no se vería satisfecha incluso si le fuera posible ir a Iraq, objeto de sus ansias:

«Del cielo de la sabiduría, soy el sol,
pero sobre mi pesa una maldición:
la de nacer en Occidente».

“Si yo apareciese en Oriente, ¿cómo se apresurarían a tomar todo lo que se ha perdido de mi renombre?"

Ibn Hazm sabía que Iraq le defraudaría tanto como España. Pensaba que era inútil ir a buscar lejos lo que se tenía al alcance de la mano ${ }^{13}$.

$Y$, a pesar de todo, él se siente orgulloso de su origen como lo confiesa en «El Collar de la Paloma»:

"Hermanos, me ofrecéis las perlas de la China;

pero escojo los rubies de Al-Andalus". (Cap.XX)

10 Cfr. García Gómez, E.: op. cit. págs. 210-211.

Cfr. Garcia Gómez, E.: op. cit. págs.249-250 y 223.

Cfr. García Gómez, E.: op. cit. págs. 310.

Cfr. Peres, H.: op. cit. págs. 57-59. 


\section{EL PENSAMIENTO DE IBN HAZM}

Ibn Hazm escribió con gran maestría sobre diferentes materias: filosóficas, jurídicas, teológicas, históricas o puramente literarias ${ }^{14}$.

Lo esencial de su pensamiento está centrado en tres problemas. $Y$ en la respuesta que da a cada uno de ellos, revitaliza el pensamiento islámico de Occidente.

1. Sobre el sentido del amor, con «El collar de la paloma».

2. Sobre derecho, especialmente, con su obra "Kitab al-Muhalla». Ocupándose entre otros aspectos de la "guerra santa" y del estatuto de la mujer».

3. Sobre religión, destacó y fue pionero en el estudio y elaboración de la historia comparada de las religiones, haciendo gala de su erudición bíblica, distinguiendo a la perfección las sectas judías. Ibn Hazm ya se dirigía a quienes pensaban que, indudablemente, entre todas las religiones del mundo, debe existir una verdadera, pero pensaba que esta religión no se manifestaba a nadie con claridad y certeza, por lo cual Dios, no impide a nadie la obligación de profesarla ${ }^{15}$. (De esta obra hizo una traducción admirable Asín Palacios, publicada en 5 vols. Madrid 1927-32, "Abenhazam de Córdoba y su Historia crítica de las ideas religiosas». Esta obra solo ha podido encontrar paralelo en la Europa del S. XIX).

Hay que tener presente, como resalta don Emilio García Gómez, que toda esta extensa obra la realizó en unas duras condiciones, pues sobre él iban dirigidas las criticas de reyezuelos y autoridades religiosas. Buena parte de su producción conserva un tono polémico. Ninguno de los reyes de taifas quería tenerlo en su reino, no sólo por sus ideas religiosas sino también por las políticas. Criticó duramente por su impiedad y crueldad al rey de Sevilla, Al-Mu'tadid (1042-1069).

\section{EL COLLAR DE LA PALOMA. TRATADO SOBRE EL AMOR $Y$ LOS AMANTES (TAWQ AL-HAMAMA)}

Cada civilización tiene una visión sobre el amor. El califato de Córdoba tuvo su visión del amor y su cronista en IBN HAZM, quien nos contó con

\footnotetext{
14 Entre los textos históricos cabe recordar la "CHAHARA», el mejor repertorio de genealogía árabe del Occidente musulmán (ed. por Levi-Provençal, 1948). El «NAQT», original y descarnado opúsculo histórico; y la «Epístola apologética de España y sus sabios», primera, aunque breve h.a literaria de al-Andalus. Cfr. García GómeZ, E.: op. cit. pág. 42.

15 Cfr. Garaudy, Pi.: op. cit. pág. 253.
} 
detalle como amaron los andalusies cuando los omeyas reinaron en alAndalus, en su obra "EL COLLAR DE LA PALOMA» que ha sido, para algunos estudiosos, no sólo la mejor obra de su autor sino la mejor en toda la literatura árabe, como manifiesta el historiador A.G. Chejne, quien la califica de obra maestra ${ }^{16}$.

La obra es una auténtica joya literaria, escrita en árabe purísimo, en opinión del arabista Emilio García Gómez, en rica prosa en la que se intercalan versos, a veces, con un profundo sentimiento, llena de historias de amor, de observaciones sobre la vida cotidiana de su tiempo. No es una disertación académica sobre el sujeto del amor, sino que narra aspectos del amor basados, en gran parte, en los sentimientos interiores de Ibn Hazm, en sus experiencias y en sus observaciones. Desde su juventud fue un gran observador de los hechos, e hizo reflexiones de índole estética y moral, que son un exponente de su penetración y retentiva.

A pesar de lo mundano del tema, «El collar» revela la sensibilidad religiosa de su autor, quien en la introducción de su trabajo aclara que teme ser acusado de frivolidad por ahondar en semejante asunto. "El collar» es un libro de intención purísima, limpia y hasta el final, ascética y piadosa. Todo ello obedece a determinadas circunstancias sociales y de ambiente moral y religioso. Hoy dia ciertas observaciones psicológicas del libro nos puede parecer pueriles, pero hay que tener presente que la obra se escribe a comienzos del siglo XI, en un momento de vacío total en la España cristiana y europea. Levi-Provençal, buen conocedor de la vida y las costumbres marroquíes, escribía, que las escenas que Ibn Hazm nos refiere en "El collar», le recordaban exactamente la atmósfera de una ciudad marroquí como Fez a comienzos de este siglo.

\section{¿DÓNDE Y CUÁNDO ESCRIBIÓ «EL COLLAR DE LA PALOMA»?}

Ya habíamos apuntado, anteriormente, como la obra se empezó a redactar en Játiva, aproximadamente, en torno al año 1022. Una vez que lbn Hazm se retiró de su actividad política, después que Córdoba había sido saqueada y medio destruida por los beréberes; por ello don Emilio Garcia Gómez, dice que «El collar» es una «elegia andaluza», una nostálgica resurrección en el recuerdo de la gran capital del Califato, en la que el autor había nacido, bajo el poder de Almanzor, y en la que había transcurrido su adolescencia dichosa y elegante.

16 Cfr. Chesne, A.G. Ibn Hazm. Chicago, Kazi Publications, 1982, págs. 132-138. 
No fue fácil para lbn Hazm escribir esta risala o epístola, él mismo lo manifiesta, así, en el epílogo de la obra: «milagro es que un ánimo como el mío haya siquiera podido acordarse de algo, conservar alguna huella y evocar el pasado, después de lo ocurrido y de lo que me cayó encima"...

Menciona la situación en la que se encuentra: desterrado de su hogar, alejado de la patria, padeciendo deslealtad de los amigos, perdida de fortuna; metido, en fin, en un cúmulo de circunstancias adversas que habían destrozado su ánimo ${ }^{17}$.

\section{¿POR QUÉ O PARA QUIÉN ESCRIBIÓ «EL COLLAR»?}

«El collar» lo escribió por encargo de un amigo, quien le pidió a través de una carta, que le compusiera una risala en la que pintase el amor, sus aspectos, causas y accidentes y cuanto en él o por él acaece. Declarando cómo es y cómo se presenta, con la mayor veracidad posible.

Para su elaboración, Ibn Hazm habla de lo que él vio con sus ojos, de lo que ha sabido por otras personas y le habían contado gentes de fiar. Al tiempo que se excusa por no citar ciertos nombres o desfigurar alguno, por tratarse de faltas que no son lícito declarar, o por miramiento a amigos queridos o a personas importantes.

A este respecto recuerda que los musulmanes están obligados a respetar los derechos de los príncipes y no deben dar más noticias que aquellas que hablen de su firmeza y de sus trabajos en pro de la religión; por lo cual no puede tratar las numerosas historias que él conoce de lo que sucede en el interior de los alcázares, cuando los personajes principales y pilares de sus reinos andan entre los amantes ${ }^{18}$.

Ibn Hazm elude citar casos, cuja veracidad le constaba, que podrían dejar perplejos a los más entendidos y llenos de asombro a los más avisados, pero no se había propuesto declarar los ardides ni contar las mañas de los enamorados. Solamente citará a aquellos que con su mención no sufran detrimento, o porque su asunto sea de todos conocido, o porque aquél de quien se trate consienta en que se publique su aventura y no tenga inconveniente en que se refiera.

17 Cfr. García Gómez, E: op. cit. págs. 309-310.

18 Ibn Hazm cita lo ocurrido a Nizar ibn Ma'add, señor de Egipto, quien por complacer a una esclava a la que amaba locamente, no vió a su hijo al-Mansur, que había de heredar el trono, sino bastante tiempo después de su nacimiento. Cfr. García GómEZ, E. op. cit. pág. 100. 


\section{¿QUÉ FIN TENIA IBN HAZM EN MENTE AL INICIAR LA OBRA?}

Así como Dante al escribir la Divina Comedia afirma que «que toda la obra fue emprendida no con un fin especulativo, sino práctico"... y que su propósito era apartar del estado de miseria a los que viven en esta vida y conducirlos hacia el estado de bienaventuranza. Ibn Hazm hace una declaración similar: «El collar de la paloma» es la "AYUDA» que Ibn Hazm le ofrece a un amigo, por el afecto que mutuamente se tienen y sin esperar más premio que la correspondencia, para que éste alcance la verdad.

En principio, el tema amoroso es un asunto «liviano», pero si el alma profundiza y se explaya, el «amor» puede ser «usado» para hacer más llevadera nuestra existencia futura y más placentera nuestra eterna morada el día de la resurrección» ${ }^{19}$.

\section{¿POR QUÉ ESTE TITULO?}

El título mismo del libro «El collar de la paloma» tiene un profundo significado vinculado con la filosofía amorosa neoplatónica tal como fue desarrollada por sus autores islámicos.

Ibn Hazm no tuvo acceso directo a Platón, pero había sentido su pensamiento y espiritu a través de las obras y los trabajos de los neoplatónicos de Alejandría, como dejan constancia las múltiples alusiones que aparecen ya en "El collar» ${ }^{20}$.

Según Ibn Dawud, hijo del fundador de la escuela zahirista en Bagdad, en cuya obra «El libro de la flor» se inspiró lbn Hazm, y al que se cita en «El collar», aquello que entre los hombres se llama «amor», entre los dioses iniciados se llama "Pteros" o "paloma revolotante".

Avicena (980-1037) contemporáneo de lbn Hazm, confirma la costumbre existente entre los poetas neoplatónicos de vincular a la paloma con el alma afirmando que la paloma es el alma caída:

«una paloma hay en ti, noble y orgullosa, caida de la más alto del cielo»...

Esta paloma al adaptarse al cuerpo ha olvidado su «mundo original».

Así, el motivo poético de una paloma portadora de un collar alude a la doctrina sufí: si bien es cierto que la paloma del alma tiene y es controlado

19 Cfr. Mújica Pinilla, R.: El Collar de la paloma del alma. Madrid. Hiperión, 1990, pág. 34.

20 Cfr. Garaudy, R.: op. cit. pág. 78. 
por un «Amo Divino» que dispone de ella (Predestinación), ella será juzgada según sus actos (Libre Albedrío). El alma es libre de tejer su propio collar, su propio destino, pero ella no puede alterar la naturaleza misma del Ser que la engendró.

En suma, podemos afirmar que la influencia de la obra de lbn Dawud y de las enseñanzas platónicas quedan reflejadas en «El collar de la paloma». Probablemente, Ibn Hazm no conoció por modo directo la obra platónica, sino a través del «Libro de la flor» de lbn Dawud.

En el último capítulo $(X X X)$ de «El collar», Ibn Hazm llega a insinuar el significado del título de su libro con un versículo del Corán: « $A$ todo hombre le hemos atado al cuello su suerte, y el día de la Resurrección le sacaremos fuera un escrito que encontrará desplegado. Lee tu escrito, le diremos: hoy basta con que tu propia alma te saque la cuentan(XVII, 14-15) ${ }^{21}$.

\section{ESTRUCTURA DE LA OBRA}

El contenido de la risala, según el mismo lbn Hazm explica en el primer capítulo de su obra, se reparte en 30 capítulos.

- 10 versan sobre los FUNDAMENTOS DEL AMOR:

- sobre la esencia del amor

- sobre las señales del amor

- sobre el que se enamora en sueños

- sobre el que se enamora por la pintura del objeto amado.

- sobre el que se enamora por una sola mirada

- sobre aquel cuyo amor no nace sino tras un largo trato

- sobre las alusiones verbales

- sobre las señas hechas con los ojos

- sobre la correspondencia amorosa

- sobre el mensajero

- 12 versan sobre los ACCIDENTES DEL AMOR y sobre sus CUALIDADES LOABLES Y VITUPERABLES:

- sobre el amigo favorable

21. Cfr. García Gómez, E.: op. cit, pág. 295. 
- sobre la unión amorosa

- sobre la guarda del secreto

- sobre su revelación y divulgación

- sobre la sumisión

- sobre la contradicción

- sobre el que habiendo amado una cualidad determinada, no puede amar ya después ninguna otra contraria

- sobre la conformidad

- sobre la lealtad

- sobre la traición

- sobre la enfermedad

- sobre la muerte

- 6 versan sobre las MALAVENTURAS que sobrevienen en el amor:

- sobre el que saca faltas

- sobre el espía

- sobre el calumniador

- sobre la ruptura

- sobre la separación

- sobre el olvido

- 2 versan sobre:

- la fealdad del pecado

- las excelencias de la castidad

El fin y conclusión de su exposición van dirigidos a predicar la sumisión a Dios Honrado y Poderoso, y a prescribir el bien y vedar el mal, como es deber de todo creyente.

A pesar de este plan previo, Ibn Hazm no se ajusta a él con toda rigidez, pues hay veces que ciertos temas se entremezclan unos con otros, de ello se excusa el propio autor.

En cada uno de estos capítulos Ibn Hazm nos ofrece un reflejo de 10 que sucedía en lo tocante al amor entre los andalusies de Córdoba, cita ejemplos concretos, algunos de los cuales recordaré a lo largo de esta 
trabajo; al tiempo que el mismo nos transmite su propio pensamiento acerca del amor. Al final dedicaremos unas líneas acerca de la sinceridad del autor, aspecto éste que ha suscitado diversas opiniones.

El primer tema que aborda Ibn Hazm después de exponer la disposición de su risala, es sobre LA ESENCIA DEL AMOR. Lo primero que señala es que el amor no está reprobado por la fe ni vedado en la Santa Ley, por cuanto los corazones se hallan en manos de Dios Honrado y Poderoso, y buena prueba de ello es que, entre los amantes, se cuentan no pocos bien guiados califas y rectos imanes.

Ibn Hazm, fiel zahirí, refiriéndose directamente al Corán y a la Sunna, subraya el carácter sacral del amor. $Y$ en esta idea insiste repetidas veces ya que había sido perseguido a causa de sus planteamientos en este terreno por el alfaquí, Abu Ishaq de Elvira. En este sentido son muchas las citas que encontramos:

"La unión de los amantes ... es la vida renovada, la existencia sublime, la alegría y los gozos duraderos, $y$, sobre todo, es una gran merced de Dios" (cap. $X X)$.

E insiste en otro pasaje: «El amor tiene siempre su culminación bajo la mirada de Dios» (cap. XXIX).

Ibn Hazm rechaza la concepción platónica, defendida por Dawud; según la cual los amantes serían los dos segmentos de una espera partida. Para el poeta cordobés la naturaleza del amor consiste en la unión entre partes del almas que, en este mundo creado, andan divididas, en relación a cómo eran en su elevada esencia.

El amor es algo que radica en la misma esencia del alma. El verdadero amor, basado en la atracción irresistible, se adueña del alma y no puede desaparecer sino con la muerte. El autentico amor es una elección espiritual y una fusión de las almas, este es el amor irresistible que no depende de otra causa que de la afinidad de las almas.

Todos los demás amores que nacen por otras causas: amor a los parientes, el de afectuosa costumbre, el que engendra la amistad y el conocimiento, el que se encamina para la obtención de un placer y la consecución de un deseo, etc... todos ellos variaran, cesaran o aumentaran en relación con la causa que lo ha creado.

Acerca de esto Ibn Hazm compuso unos versos:

«Mi amor por ti, que es eterno por su propia esencia, ha llegado a su apogeo, y no puede menguar ni crecer. No tiene más causa ni motivo que la voluntad de amar»... 
Respecto al hecho de que «NAZCA el amor», Ibn Hazm piensa que, en la mayor parte de los casos es por la belleza; es evidente que el alma es bella y por tanto, suspira por todo lo hermoso, y siente inclinación por las imágenes perfectas; y si luego distingue tras esa imagen alguna cosa que le sea afín, se une con ella y nace el verdadero amor; pero si no distingue tras esa imagen nada afín a sí, su afección no pasa de la forma y se queda en apetito carnal.

En suma, manifiesta «el amor es una dolencia rebelde, cuya medicina está en si misma, si sabemos tratarla; pero es una dolencia deliciosa y un mal apetecible, al extremo de que quien se ve libre de él reniega de su salud y el que lo padece no quiere sanar» ${ }^{22}$.

Ibn Hazm reconoce que, mientras las ciencias médicas son útiles para estudiar los «accidentes» del amor. Las "causas" del amor sólo pueden ser discernidas a la luz de la metafísica. Lo físico y lo psíquico no pueden ser comprendidos independientemente de lo espiritual y de lo divino ${ }^{23}$.

El amor, además, torna bello a ojos del hombre aquello que antes aborrecía, y le hallan lo que antes le parecía difícil, hasta el punto de trastornar el carácter innato y la naturaleza congénita». Por amor, los tacaños se hacen desprendidos; los huraños desfruncen el ceño; los cobardes se envalentonan; los ásperos se vuelven sensibles; los ignorantes se pulen; los desaliñados se atildan; los sucios se limpian; los viejos se las dan de jóvenes; los ascetas rompen sus votos, y los castos se tornan disolutos ${ }^{24}$.

Estas y otras muchas más son las señales e indicios de amor; aunque podríamos citar, también, la animación excesiva, el estar juntos donde hay mucho espacio, el deseo de oír el nombre del amado, la afición a la soledad, que el amante espíe al amado, tome nota de cuanto diga, investigue cuanto haga, sin que se le escape cosa alguna, y le siga en sus movimientos. Ibn Hazm puntualiza que en este asunto se podrá comprobar como los necios se vuelven listos y los incautos, agudos.

A propósito de los síntomas o señales del amor, ibn Hazm relató un suceso que le contaron en Almería. Un personaje le preguntó a un médico judío experto en el arte fisiognómica que pensaba acerca de un joven que pasaba por delante de su tienda, el médico le miró un momento y dijo:

\footnotetext{
22 Es curiosa la similitud que tienen estas palabras con el villancico que compuso el salmantino JUAN DEL ENZINA (1468-1529): «más vale trocar plazer por dolores que estar sin amores"... O "mejor es sufrir pasión y dolores que estar sin amores", o "mejor es penar sufriendo dolores que estar sin amores".

23 Cfr: MúJica PiniLla, R.: op. cit. pág. 69.

24 Cfr. Garcia Gcmez, E.: op. cit. págs. 102 y 110.
} 
"Que es un enamorado", acertaste dijo quien se lo había preguntado; pero ¿Cómo lo sabes? le preguntó: No más que por la excesiva abstracción que lleva pintada en el semblante, sin entrar en otros ademanes, por ello he deducido que se trata de un enamorado, sin que haya lugar a dudas ${ }^{25}$.

Uno de los ASPECTOS del amor es "LA UNIÓN AMOROSA", que constituye una sublime fortuna, un grado excelso, la vida renovada (semejanza con la obra de Dante "La vita nova»), la existencia perfecta, es la serenidad imperturbable, el gozo sin tacha que lo empañe ni tristeza que lo enturbie, la perfección de los deseos y el colmo de las esperanzas. Ibn Hazm reconoce haber tenido otros muchos placeres como: el favor del sultán, el dinero, el ser algo tras no ser nada, etc... pero nada de todo eso le ha encendido la pasión, ni nada puede causar más placer que el que siente el amante en la unión amorosa. Incluso cuando el amante no puede conseguir la unión amorosa, tiene que conformarse con lo que pueda obtener, en ello existe alguna distracción para el alma, al menos un cierto alivio, y recuerda como alguien conocido suyo había dicho a su amado: "Hazme una promesa, aunque no la cumplas" ${ }^{26}$.

Recuerda y nos transmite sus sentimientos personales en una ocasión que se reunía con una de sus amadas, y refiere que cuanto más se acercaba a ella, más crecía su agitación, y el pedernal del deseo encendía con mayor fuerza el f́uego de la pasión en sus entrañas. Acerca de esto compuso estos versos:

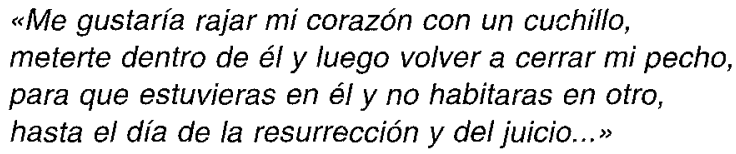

"Me gustaría rajar mi corazón con un cuchillo, meterte dentro de él y luego volver a cerrar mi pecho, para que estuvieras en él y no habitaras en otro, hasta el día de la resurrección y del juicio...”

Afirma Ibn Hazm que no hay el mundo condición que iguale a la de los amantes cuando se equiparan en sus gustos y se corresponden en el amor... pero, añade, que es ésta una gracia que muy pocos logran y un regalo que no se otorga a todo el que lo solicita. A propósito de esto cuenta una anécdota:

"Se cuenta que ZIYAD ibn Abi Sufyan dijo a sus comensales. ¿quién es el hombre que lleva la vida más feliz?, le respondieron: «El Príncipe de los Creyentes", pero él objetó ¿Y dónde dejáis lo que tiene que sufrir con los Qurays?", y le dijeron: "Entonces eres tú», pero él objetó: ¿Y dónde dejáis

25 Cir. Garcia Gómez, E.: op. cit. pág. 118.

26. Cfr. García Gómez, E. op. cit. pág. 231. 
lo que tengo que sufrir con los Jarichies y con la defensa de las fronteras?, Le dijeron: "Entonces ¿quién es? y contestó: "Un hombre musulmán que tenga mujer musulmana, con medios bastantes para vivir; que se gusten él a ella y ella a él; que no nos conozca y a quien no conozcamos" ${ }^{27}$.

Ibn Hazm habla también de la «unión clandestina», que burla a los espías y se resguarda de los presentes, que se declara en sonrisas a hurto, toses fingidas, señales hechas con las manos, y que produce en el alma una sensación deleitosa. A este respecto recuerda la historia que le contó un amigo suyo de lo que le había ocurrido cuando era joven. Y era que estando enamorado de una esclava que vivía en una de las casas de su familia y que era inaccesible para él y por ella tenía perdida la cabeza, se celebró una fiesta en el campo, en el llano que hay a poniente de Córdoba; y de pronto comenzó a llover y como en las cestas de las viandas no había mantas para todos, su tío, anfitrión de la fiesta, mandó traer una de las mantas, se la echó encima y mando a la esclava que se cobijara con él, y dice textualmente: ¡lmagínate lo que fue aquella posesión ante los ojos de todos y sin que se dieran cuenta!, añade, ¡Jamás olvidaré aquél día! Sobre este asunto lbn Hazm compuso una poesía:

"Ríe el jardín, mientras las nubes lloran, como el amado cuando lo ve el afligido amante» ${ }^{28}$.

A veces, la unión amorosa viene a ser tan dulce y los corazones se aúnan de tal modo; que los amantes llegan a despreciar el qué dirán, a no cuidarse de los chismeros, e incluso las hablillas acrecientan su deseo. Sobre ello compuso otro poema:

" Cuántas vueltas di en torno del amor, hasta caer en él, como la mariposa a la luz!".

De todos los demás capítulos el más difundido del libro y el que independientemente ha pasado a otras obras es el capítulo referente a «LAS SEÑALES DEL AMOR».

Tiene el amor señales que persigue el hombre avisado y que puede llegar a descubrir un observador inteligente. Señala como la señal principal de todas, la insistencia de la MIRADA porque es el ojo la puerta abierta del alma, que deja ver sus interioridades, revela su intimidad y delata sus secretos. Sobre esto compuso un poema:

27 Cfr. García Gómez, op. cit. pág. 186.

28 Cfr. García Gómez, op. cit. págs. 188-89. 
"Mis ojos no se paran sino donde estás tú.

Debes de tener las propiedades que dicen del imán.

Los llevo adonde tú vas y conforme te mueves,

como en gramática el atributo sigue al nombre».

Los ojos juegan, a este respecto un laudable papel y rinden efectos maravillosos. Con la mirada se aleja y se atrae, se promete y se amenaza, se ordena y se veda, los ojos hacen a menudo de mensajeros, con ellos se da a entender lo que se quiere. La VISTA, para Ibn Hazm, es el más eficaz de los sentidos y el que produce los más eficaces resultados ${ }^{29}$.

Otras señales son: que no pueda dirigir el amante la palabra a otra persona que no sea su amado, aunque se lo proponga, que calle embebecido cuando hable el amado; que encuentre bien lo que diga aunque sea un puro absurdo, que el amante vuele presuroso hacia el sitio en que está el amado, que busque pretextos para sentarse a su lado y acercarse a él; la sorpresa y ansiedad que se observa en el rostro del amante cuando impensablemente ve a quien ama, o éste aparece de súbito.

Otros capítulos están dedicados al modo de enamorarse, y habla de aquellos que se enamoran en sueños; o quienes se enamoran por oír hablar del ser amado; o quienes se enamoran POR UNA SOLA MIRADA, esta página es una de las más bellas del libro. En este caso lo que puede ocurrir es que el amor se consuma rápidamente o perdure. Para lbn Hazm, «las cosas que crecen de prisa, de prisa se consumen, en tanto que las que tardan en nacer tardan también en acabarse.

No obstante, cuenta el caso de lo que le sucedió al conocido poeta AlRamadi, historia muy conocida y divulgada, que cuando pasaba por la Puerta de los Drogueros de Córdoba, que era el sitio de reunión de las mujeres ${ }^{30}$, vio a una muchacha que, según el mismo refirió, "se apoderó de todas las entretelas de su corazón y cuyo amor se filtró por todos los miembros de su cuerpo"; dejó entonces el camino de la Mezquita a donde

29 Ibn Hazm describe las señas que se hacen con los ojos: Una mirada languida es prueba de aceptación; la persistencia de la mirada es indicio de pesar y tristeza; la mirada de refilón es signo de alegría; el entornar los ojos da a entender amenaza. El mover la pupila con rapidez desde el centro del ojo hacia la comisura interna indica imposibilidad. Mover ambas pupilas desde el centro de los ojos es prohibición absoluta, etc... Las demás no pueden comprenderse sino viéndolas. Cfr. García Gómez, E.. op. cit. pág. 140.

30 El viernes era el día en que salían las mujeres, y los caminos de los cementerios se llenaban una vez terminada la oración en la Mezquita Mayor, de una multitud de ambos sexos. Cordobeses y cordobesas se dirigían sobre todo a la necróplis del Arrabal,atravesando el Puente Romano hacia Secunda. Los jovenes buscaban aventuras y acechaban a las mujeres solas. Cfr. Levi-Provençal, E.: La España Musulmana, T.V. de la $\mathrm{H}^{a}{ }^{a}$ de España dirigida por Menéndez Pidal, R. Madrid. Espasa Calpe, 1973, pág. 285. 
se dirigía y comenzó a seguirla, describe los lugares por donde pasaron, el Arrabal, los jardines de los Banu Marwan trazados sobre sus tumbas, etc..., y ella al ver que la seguía le preguntó ¿qué deseaba de ella y por qué la seguía?, él le manifestó el gran tormento que por ella sentía. Ella le dijo que dejase esas cosas y que no la buscase la perdición, él manifestó que se contentaba con mirarla, le preguntó si era libre o esclava, a lo que ella respondió que era esclava y que se llamaba Jalwa (Soledad), le preguntó quien era su amo, y donde podría volver a verla, ella le citó en el mismo lugar el siguiente viernes; pero ella no volvió. Él la recuerda en múltiples poemas, viajó a Zaragoza en su búsqueda y sólo un tiempo más tarde volvió a encontrarla ${ }^{31}$.

Otros, por el contrario, se enamoran después de un LARGO TRATO, de mucho verse y de una dilatada convivencia y a ellos dedica otro capítulo Ibn Hazm. Para Ibn Hazm este es el amor que suele durar y en el que no hace huella el paso del tiempo. Por que según dice un proverbio:

"Lo que entra con dificultad no sale con facilidad".

Ibn Hazm refiere como notaba que entre las gentes que él conoció había algunos que al notar en su alma afecto naciente o al advertir en sus gustos determinada inclinación por ciertas imágenes, recurrían a la huida y a cortar toda visita, para que sus sentimientos no aumentasen.

El mismo se confiesa y declara que jamás prendió ningún amor en sus entrañas, "sino después de haber pasado mucho tiempo, luego de haber convivido largamente con una persona y de haber compartido con ella chanzas y veras». Y vuelve a incidir, como ya hizo en otro capítulo anterior, que lo que ocurre en un primer momento sólo son accidentes de atracción corporal y de aprobación visual, que no van más allá de las apariencias físicas y ahí radica el secreto del apetito carnal. Este apetito solamente tomará el nombre de amor, cuando traspase estos límites, siempre que su rebasamiento coincida con una unión espiritual en que tengan parte el alma y sus cualidades naturales.

Un capítulo que reviste interés por su relación con las costumbres y su posible influencia posterior es el referente al MENSAJERO a quien habrá que buscar con el mayor cuidado posible. Las personas más empleadas por los amantes para comunicarse con los que aman son, o bien los criados, en quien nadie despiertan recelos por su corta edad; o bien,

${ }^{31}$ Cfr. LeVI-Provençal, E.: «En relisant le «Collier de la Colombe», Al-Andalus, XV, 1950 , pág. 340 , nota 3 . 
por el contrario, personas respetables, y fuera de sospecha por la piedad que aparentan o por la avanzada edad a la que han llegado; o también las personas que tienen oficio que suponen trato con las gentes: vendedoras, curanderas, plañideras, cantantes, etc... $\mathrm{O}$ aquellas otras que tienen parentesco con aquél a quien son enviadas. Nos recuerda a las futuras Trotaconventos y Celestinas.

También señala como algunos amantes usaban como mensajero a una PALOMA amaestrada, en cuyas alas ataban las cartas.

Otra de las señas de amor suele ser que el amante REFRENE SU LENGUA por muchos motivos: a veces se encubre el amor porque el amante se retrae de presentarse ante la gente como un enamorado, porque a su juicio, es condición de gente de poco seso, y por ello huya de él y se abstenga de usarlo. Para lbn Hazm esto no es razonable, pues el musulmán debe abstenerse de las cosas que están vedadas por Dios, pero el hecho de que el amor se apodere de uno, es cosa natural, que no está mandada ni vedada.

Cuenta como conoció a uno a quien el amor se había aposentado en su pecho y él pretendía negarlo, hasta que la cosa creció de tal modo que podía leerla en su rostro tanto el que quería saberlo como él que no; él trataba siempre de negarlo hasta que un día pasó de improviso su amada y a éste se le demudó la color, y sus razones que eran antes muy concertadas se tornaron incoherentes, hasta el punto de que interlocutor dejó de hablarle.

Otra de las causas del encubrimiento del amor es, a veces, el deseo del amante de salvaguardar a su amado, lo cual es señal de lealtad y de noble condición. Otro motivo, es el miedo del amante por su propia vida, si revela su secreto por el alto linaje del amado, como sucedió a un poeta de Córdoba que compuso unos versos amatorios dedicados a Subh, madre de Hisam II, quien contribuyó al encumbramiento de Almanzor. Un día una esclava cantó aquellos versos ante Almanzor para ver si la compraba, Ipero el efecto que produjo fue el contrario, pues Almanzor, indignado, mandó matarla.

Una de las cualidades que destaca Ibn Hazm, tanto en el amor como en otros aspectos, es la LEALTAD. El hombre debe ser leal a quien lo es con él e incluso con quien es traidor. Y ésta es una obligación, tanto para el amante como para el amado, y únicamente se apartan de ella las gentes de baja cuna, las mal criadas y en quienes nada bueno puede hallarse.

En este sentido recuerda uno de los casos más conmovedores que el conoció. Un amigo consistió en romper con su amado, la persona que le 
era más cara y querida, por guardar un secreto que tenía confiado. Su amado le obligó bajo solemne juramento a no dirigirle jamás la palabra y a cortar las relaciones; a menos que le contase aquel secreto; pero el amante rehusó hacerlo y persistió en ocultarlo. El tiempo los separó. Ibn Hazm como ya vimos, se jacta de ser muy leal ${ }^{32}$.

Señala lbn Hazm dentro de los ACCIDENTES del amor: la enfermedad y la muerte. Las dolencias de amor es algo frecuente y las sufren aquellos amantes, cuyo amor es sincero y no pueden gozar de la unión amorosa, por diversas circunstancias. A veces, la dolencia del amante puede llegar a hacerle perder del todo la razón, a trastornar su inteligencia y a obsesionarle, el motivo no es otro que la idea fija.

Ibn Hazm cita dos casos concretos de personas conocidas que se volvieron locos al enamorarse perdidamente de una esclava, cuyo amor no fue correspondido pues se vendieron a otras personas, en el primer caso, la vendió un hermano, y en el segundo, la vendió la madre del joven.

A veces, esta dolencia amorosa puede llevar incluso a la muerte. Tal es el caso del secretario, Ibn Quzman, que anduvo tan perdido por Aslam, verdadero portento de hermosura que este amor le hizo caer en cama y acabó por llevarlo a la muerte. Aslam lo trataba mucho y lo visitaba a menudo, pero nunca supo que él mismo era la causa de su enfermedad, hasta que Ibn Quzman murió de pena y tras larga dolencia.

Algo similar ocurrió a la cuñada de Ibn Hazm, llamada, 'Atika, quien durante el tiempo que duró la separación de su esposo, ocho años, motivada por un enfado, el amor que sentía por él la hizo adelgazar, la pasión la extenuó de tal forma que se quedó como un espectro. Murió al año siguiente de morir su esposo a causa de la peste que hubo en Córdoba.

$\mathrm{O}$ aquella otra historia de su amigo Ibn Al-Tubni, quien también murió a causa de no superar el amor que sentía por un joven mancebo. Le sucedió ésto a pesar de que, aclara Ibn Hazm, su amigo era de quienes nunca sufrieron aberraciones, ni transgredieron las lindes de lo ilícito.

El amante, en su mal de amores, puede quedar tan delgado que resulta invisible, refiere Ibn Hazm. En "El collar» se pueden leer estos versos:

El amor, dueño mío, me dejó tan extenuado, que no pueden verme los ojos de los que me visitan ${ }^{33}$.

32 Cir. García Gómez, E.. op. cit. pág. 211.

33 Cfr. Teres, E.: Enseñanzas de lbn Hazm, op. cit. pág. 161. 
Respecto a las MALAVENTURAS que sobrevienen en el amor, Ibn Hazm hace referencia al ESPIA, al cual compara con una fiebre oculta, o una pleuresía crónica. Cita como caso curioso la historia de dos enamorados que amaban a la misma mujer, y él recuerda que cada uno era el espía de su contrincante, sobre este asunto compuso unos versos:

Estos dos jóvenes... "se parecian al PERRO del establo, que no come heno y no lo deja comer a ningún otro" 34 .

Otra de las penalidades del amor es LA RUPTURA que puede estar producida por muchos factores: por la coquetería, el reproche, el odio, los maldicientes, el hastío, etc... A ella se refiere así lbn Hazm:

¿Qué fea la ruptura tras la unión

y qué bella la unión tras la ruptura!

Esto es como ser rico tras ser pobre;

aquello, como ser pobre tras ser rico.

Pero peor que la ruptura es la SEPARACIÓN, hay mucha gente que se acoge a la ruptura por miedo a la separación, pero no recuerda ningún caso contrario, que se acogía a la separación por miedo a la ruptura. La separación puede ciurar un espacio de tiempo determinado pero, a pesar de ello, produce desasosiego en el corazón, que no desaparece sino con la vuelta. Narra como un amigo suyo que residía en Almería tuvo que ir a Játiva por motivos de trabajo, y se alojó en su casa, pero por causa de la guerra se demoró su regreso a Almería donde había dejado un amor, y, por ello, a punto estuvo de morir de pena.

El propio Ibn Hazm confiesa haber sufrido por la separación de la esclava Nu'm. Y a propósito de ello se detiene en analizar qué situación es la peor la separación, la ruptura o la muerte, siendo, para él, preferible ésta última a la separación.

Por último, para finalizar este repaso a la estructura de la obra voy a referirme a los dos últimos capítulos, referentes a la FEALDAD DEL PECADO y a la CASTIDAD.

Ibn Hazm recuerda que Dios puso en el hombre dos naturalezas opuestas: una de ellas, que es el entendimiento guiado de la justicia, no lleva sino a la virtud; la otra, que es la concupiscencia, guiada de la pasión, lleva

\footnotetext{
34 Es curioso encontrar en el s. XI nuestro actual refrán: «Como el perro del hortelano que ni
} come ni deja comer a su amo». 
a los apetitos y no aboca sino a la perdición. Así se recoge en el Corán: «En verdad el instinto arrastra al mal» (XII, 53). Esas dos naturalezas son como dos polos, y entre ellas están en guerra perpetua y en continuo litigio. $\mathrm{Si}$ el entendimiento vence a la concupiscencia entonces obra el hombre con cautela; pero si la concupiscencia vence al entendimiento, entonces el hombre cae en el abismo de la perdición. En este sentido hombres y mujeres son iguales ante la inclinación por los pecados de maledicencia y concupiscencia.

Ibn Hazm confiesa ser puro en sus costumbres; e incluso jura que jamás desanudó su manto para un coito ilícito y que Dios no habría de pedirle cuenta de ningún pecado grave de fornicación desde que tuvo uso de razón hasta el momento en que redacta esta obra. Este proceder suyo es debido a las enseñanzas que recibió de su maestro Abu 'Alí, quien le hizo ver los efectos de la depravación y la fealdad del pecado.

Refiere como estando en casa de una mujer conocida suya encontró en ella a una joven con la cual se había criado, era una muchacha muy bella, y confiesa que estuvo a punto de caer en los devaneos juveniles, pero se abstuvo de volver a entrar en aquella casa, porque nunca hay que fiarse de que el demonio no nos asalte de improviso.

Dedica una atención especial al adulterio, a las relaciones ilícitas, a las cuales condena, y únicamente se atreve a decir que si el instinto sexual no estuviese tan arraigado en el hombre, Dios no hubiera sido tan benigno con los solteros $y$, en cambio, tan rígido con los casados. Y puntualiza que esto es así tanto en la Ley islámica como en las otras antiguas reveladas por Dios.

Lógicamente, en contraposición a lo dicho, una de las mejores cosas que puede hacer el hombre en sus amores es guardar CASTIDAD. Entre las tradiciones piadosas se halla la siguiente: «El que se enamora y es casto y muere, muere mártir» ${ }^{35}$.

Refiere en este sentido io que sucedió al emir Muhammad, hijo de alHakam. Cuando su padre tuvo que ausentarse del alcázar por unos meses, ordenó que su hijo estuviese en la azotea sin poder salir para nada, y que cada noche le acompañase uno de los visires y uno de los grandes fatàs (funcionario palatino), y refiere uno de los visires que una

\footnotetext{
35 Esta sentencia que ha llegado a ser atribuida incluso al Profeta, es uno de los pilares del «amor'udri». Cfr: García Gómez, E. op. cit. pág. 327, nota 1. El término amor 'udri procede de la tribu "Banu Udra", hijos de la virginidad. No hay relación física, únicamente el fin es la unión intelectual de los amantes.
} 
noche le tocó su turno de guardia junto a uno de los fatàs más hermosos, y pensó que aquella noche el emir Muhammad sucumbiría a los embates del pecado e iría en pos del joven. Durante la noche observó como el príncipe se incorporaba varias veces en la cama y luego volvía a acostarse, y la tercera vez que lo hizo echó los pies fuera de la cama, estuvo así durante unos momentos y, por fin, llamó al paje por su nombre, y cuando éste le respondió le dijo: "sal de la azotea y quédate en el pórtico que hay debajo». El joven salió y Muhammad volvió a su lecho.

\section{OTRAS CONSIDERACIONES}

¿Fue sincero IBN Hazm al escribir «El collar de la paloma»?

De lo que hemos visto hasta aquí deducimos que el libro es personal. La obra es, en cierto modo, su autobiografía y la autobiografía de las gentes que le rodearon, sin bien como vimos Ibn Hazm prescindió de dar nombres propios de personajes conocidos. La obra es en definitiva la única evocación eficaz que poseemos sobre lo que fue la civilización cordobesa en los últimos días del Califato.

Pero la «sinceridad» del poeta se ha puesto en entredicho por varios autores. Dozy, al igual que Miguel Asín, defiende la sinceridad del autor y pone ejemplos de como transmite su propia ingenuidad y encanto, $y$, es más, Ibn Hazm era, a su juicio, el más cristiano de los poetas musulmanes, y por eso algo quedaba siempre en el fondo de su corazón, algo limpio, delicado y espiritual, que no era árabe. Es cierto que se observa en sus poemas reminiscencias de su formación cristiana, alude a las damas, mediadoras, que portaban rosarios, y, también compuso un poema que dice:

«Viniste a mi cuando la media luna salía en el cielo un poco antes de que tocasen las campanas los cristianos..." ${ }^{36}$.

Frente a estos arabistas, el escritor egipcio Taha Husein, defiende la radical insinceridad de Ibn Hazm. Para él el libro no es personal, ni subjetivo, sino que es más bien un recetario poético-retórico sobre el tema amoroso, en el que el autor pasa revista y habla de todas las situaciones, poniéndose en cada caso y hablando de él según los cánones de la preceptiva árabe.

36 E. GARCía GómEZ afirma que el toque al que aquí se alude corresponde al ángelus vespertino.Cfr. págs. 281 y 330 , nota 18 . 
Don Emilio García Gómez se queda en un término medio. Ibn Hazm escribió con gran sinceridad, pero también es verdad que se ajustó a las normas poéticas. Un ejemplo, Ibn Hazm refiere en alguna ocasión, (capítulo II), que él había llorado, cuando en otro lugar afirma que por una enfermedad que sufrió de niño sus ojos no pueden derramar lágrimas, pero él mismo aclara que si lo escribió de este modo era para ajustarse a las normas de la poesía que así lo establecen. También alude en otra ocasión, en el epílogo de su obra, a que había tratado de no salirse de los «métodos y costumbres de los poetas».

\section{DIFUSIÓN DE LA OBRA}

«El collar de la paloma» es un libro que tuvo una gran divulgación pues ha sido traducido a las principales lenguas. Después de su publicación en árabe, la obra fue traducida al ingles por Nykl, 1931; Algo más tarde, fue Francesco Gabrieli quien la tradujo al italiano y ese mismo año, Bercher la presentaría en versión francesa. En 1952, el citado Emilio García Gómez la publicó en español.

\section{POSIBLES INFLUENCIAS DE «EL COLLAR DE LA PALOMA»}

Sobre este aspecto también encontramos disparidad de criterios, pues la conocida pugna entre Américo Castro y Sánchez Albornoz queda reflejada en este punto.

Para Américo Castro «El collar de la paloma» guarda semejanzas con el Libro del Buen Amor del Arcipreste de Hita en el que Castro ve un reflejo de la estructura literaria de la obra de lbn Hazm. La narración seguida de glosa moral, la reiteración de temas análogos, el doble y reversible sentido de cuanto se dice, todo ello se encuentra en "El collar" y en otros tratados árabes de ascética y mística.

El libro de Ibn Hazm se conserva en una refundición del s.XIV, pero Castro ignora si Juan Ruiz lo conoció por tradición escrita u oral, viva ésta última en cualquiera de las miles de personas capaces de entender lo esencial de ambas lenguas.

Américo Castro señala los paralelismos existentes entre los «indicios del amor lascivo" del carmelita fray Joseph de Jesús María, según aparecen en su libro «Excelencias de la virtud de la castidad» (Alcalá, 1601), y el capítulo "sobre los síntomas del amor» de «El collar de la paloma». Y deduce de ello 
que este capítulo, fue conocido, de alguna manera, por los médicos árabes y transmitido, por ellos, a los autores hispanos de los siglos XVI y XVII ${ }^{37}$.

Por su parte, Sánchez Albornoz no está de acuerdo en enmarcar el libro del Buen Amor en la tradición literaria hispano-arábiga. Para don Claudio existen grandes diferencias tanto en la vida como en las obras de Juan Ruiz y de Ibn Hazm. Este último tuvo, como vimos, una vida inquieta, muy opuesta por tanto a la del clérigo castellano: sedentario, cauto, humilde, anclado en lo popular y contagiado del naciente espíritu burgués. Y esta misma divergencia se observa en sus obras. El poeta cordobés tiene del amor la ambigua idea de los andaluces de su generación, que no excluía las «amistades particulares», ni la sentimental inclinación de varón a varón. Mientras que en la obra del Arcipreste de Hita triunfa la simplista concepción heterosexual del amor de la Castilla de su época, enmarcada en la monogamia y a lo sumo claudicante ante la barraganía.

Sánchez Albornoz piensa que si el Arcipreste hubiese conocido la obra de Ibn Hazm habría tenido a su disposición una magnífica e inagotable cantera de ideas, reflexiones, noticias que aprovechar en su «Buen Amor».

Respecto a la figura de «Trotaconventos», Sánchez Albornoz piensa que la tercería debió de estar muy arraigada en la corrompida sociedad del primer siglo del Imperio Romano e iría creciendo a medida que la renovación de la moral por obra del cristianismo y la crisis creciente de la vida urbana fueron dificultando el libre juego del amor. Por lo que afirma que de la España musulmana sólo aceptaron los cristianos el nombre, no la institución, como ocurrió con otros términos.

\section{CONCLUSIONES}

Todo el libro constituye un análisis de los sentimientos amorosos y del comportamiento de los amantes, ilustrado con múltiples anécdotas concretas, aunque no siempre resulta fácil determinar quién es el ser amado, si se trata de una muchacha o bien de un joven, ni cuál puede ser su condición social, pues por regla general se le designa muy vagamente.

Lo que si destaca el libro es que casi todas las mujeres a las que hace referencia son de condición ESCLAVAS, esto es lógico si pensamos que

37 Cfr. Samso, J.: «En torno al «collar de la paloma «y la medicina», Al-Andalus, XL, 1975, pág. 213. También en la obra de A. Castro: «La realidad histórica de España», ed. 1954, podemos leer las analogías literarias de ambas obras, págs. 424-429. 
las mujeres de condición social elevada solían vivir recluidas en las viviendas, y las mujeres de las que cabía fácilmente enamorarse era de las que no llevaban velo y exhibían su rostro en fiestas, y éstas eran, por regla general las esclavas, que disfrutaban de una libertad mucho mayor que las mujeres libres.

De la lectura de "El collar de la paloma" podemos deducir que las relaciones entre el medio masculino y femenino no eran muy distintas en la España Musulmana y en las demás regiones del mundo islámico. En España las relaciones entre los amantes son muy semejantes a lo que ya encontramos, dos siglos antes, en la corte de Bagdad.

La protección del honor de las mujeres legítimas, que se confunde con el del linaje, llevaba consigo un enclaustramiento rígido y las mujeres con las cuales se contrae matrimonio no son, salvos casos contados, aquéllas a las que se ama ${ }^{38}$.

En resumen, sea lo que fuere, lo cierto es que Ibn Hazm fue la máxima figura de la literatura arabigoandaluza, y tienen el honor de ser una de las más puras encarnaciones del alma de la España musulmana, pues su obra es, en definitiva, la única evocación eficaz que poseemos sobre lo que fue la civilización cordobesa en los últimos días del Califato ${ }^{39}$.

38 Cfr. GuichafD, P.: Al-Andalus. Estructura antropológica de una sociedad islámica en Occidente, pág. 169.

${ }^{39}$ Cfr. «El collar de la paloma». Madrid, Alianza Editorial, 1997. Prólogo y Álbum de M. ${ }^{{ }^{\mathrm{J}}} \mathrm{J}$. Viguera Molins, pág. 70. 